\title{
CRISPR-guided programmable self-assembly of artificial virus-like nucleocapsids
}

\author{
Carlos Calcines-Cruz ${ }^{\mathrm{a}}$, Ilya J. Finkelstein ${ }^{\mathrm{b}, \mathrm{cd}, *}$, and Armando Hernandez-Garcia ${ }^{\mathrm{a}, *}$ \\ ${ }^{\text {a }}$ Department of Chemistry of Biomacromolecules, Institute of Chemistry, National Autonomous University of Mexico, Mexico \\ City C.P. 04510, Mexico \\ ${ }^{b}$ Department of Molecular Biosciences, University of Texas at Austin, Austin, Texas 78712, USA \\ ${ }^{\mathrm{c}}$ Institute for Cellular and Molecular Biology, University of Texas at Austin, Austin, Texas 78712, USA \\ ${ }^{\mathrm{d}}$ Center for Systems and Synthetic Biology, University of Texas at Austin, Austin, Texas 78712, USA \\ ${ }^{1}$ Correspondence: armandohg@iquimica.unam.mx and ilya@ finkelsteinlab.org
}

\begin{abstract}
Designer virus-inspired proteins drive the manufacturing of more effective and safer gene-delivery systems as well as simpler models to study viral assembly. However, the self-assembly of engineered viromimetic proteins on specific nucleic acid templates, a distinctive viral property, has proved difficult. Inspired by viral packaging signals, we harness the programmability of CRISPR-Cas12a to direct the nucleation and growth of a self-assembling synthetic polypeptide into virus-like particles (VLP) on specific DNA molecules. Positioning up to ten nuclease-dead Cas12a (dCas12a) proteins along a 48.5 kbp DNA template triggers particle growth and full DNA encapsidation at limiting polypeptide concentrations. Particle growth rate was further increased when dCas12a was dimerized with a polymerization silk-like domain. Such improved self-assembly efficiency allows for discrimination between cognate versus non-cognate DNA templates by the synthetic polypeptide. Our CRISPR-guided VLPs could help develop programmable bio-inspired nanomaterials with applications in biotechnology as well as viromimetic scaffolds to improve our understanding of viral self-assembly.
\end{abstract}

Keywords: virus-like particles, artificial protein, Cas12a, assembly kinetics, DNA curtain, diffusion barriers

\section{Introduction}

Virus-like particles (VLPs) mimic the capability of some viruses to encapsulate and protect genetic material from degradation by nucleases. We have previously described VLPs formed by the self-assembly of a tri-block polypeptide $\left(\mathrm{C}-\mathrm{S}_{10}-\mathrm{B}\right)$ that functionally mimics the tobacco mosaic virus coat protein ${ }^{1}$ (Fig. 1a). C-S $10-\mathrm{B}$ fuses three independent blocks: 1) "C" ( 400 aa), a random coil collagen-like domain that consists mostly of glycine, proline and uncharged polar amino acids ${ }^{2} ; 2$ ) "S $\mathrm{S}_{10}$ ", a silk-inspired polymerization domain with the sequence $\left[(\mathrm{AG})_{3} \mathrm{QG}\right]_{10}$ that is responsible for $\mathrm{C}-\mathrm{S}_{10}-\mathrm{B}$ self-assembly into rod-like structures $^{3-5}$; and 3) "B", a cationic dodecalysine stretch that interacts electrostatically with nucleic acids and other polyanions ${ }^{6,7}$. C-S $10-\mathrm{B}$ nucleates (without sequence specificity) on double stranded DNA (dsDNA), albeit with a preference for free DNA ends ${ }^{8}$. After ratelimiting nucleation, C-S $10-\mathrm{B}$ filaments grow rapidly through elongation ${ }^{1,9}$, similar to the assembly of the tobacco mosaic virus coat protein on the genomic ssRNA.

Viral coat proteins preferentially encapsulate their own genomes. They achieve such specificity by encoding one or more packaging signals along the viral DNA or RNA. These sequences bind capsid proteins with high affinity ${ }^{10-17}$ and decrease the energy barrier for nucleation, thereby promoting encapsidation of the viral genome among a vast excess of cellular nucleic acids ${ }^{18-21}$. We reasoned that designer VLPs can also leverage a similar packaging signal to enhance nucleation at specific DNA sites. We chose the catalytically dead CRISPR-Cas12a (dCas12a) as a programmable nucleation signal because it binds dsDNA with $50 \mathrm{fM}$ affinity, has a higher DNA binding specificity than $S$. pyogenes Cas $9^{22}$, and can be directed to multiple sites along the DNA via pooled CRISPR RNAs (crRNAs) ${ }^{23}$.
We decorated a DNA template with multiple dCas12a or dCas12a coupled to the $\mathrm{S}_{10}$ polymerization domain and favored DNA encapsidation by the synthetic polypeptide $\left(\mathrm{C}-\mathrm{S}_{10}-\mathrm{B}\right)$. Self-assembly kinetics were monitored in real-time using the single-molecule DNA curtain assay (Fig. 1b) $)^{24,25}$. For this, arrays of DNA molecules (48.5 $\mathrm{kbp}$, derived from $\lambda$-phage) are affixed to a lipid bilayer via a biotinstreptavidin linkage in a microfluidic flowcell. Microfabricated chrome barriers are used to organize thousands of DNA strands for highthroughput data collection and analysis. The surface-immobilized DNA is extended for fluorescent imaging via the application of mild buffer flow. DNA length was monitored along the experiment since timedependent DNA contraction is a direct readout of VLP filamentation (Fig. 1c) $)^{1}$.

\section{$\underline{\text { Results }}$}

First, we identified the minimal concentrations for efficient encapsidation of individual dsDNA substrates by $\mathrm{C}-\mathrm{S}_{10}-\mathrm{B}$ alone. At 100-300 nM, C-S $10-\mathrm{B}$ monotonically condensed individual DNA molecules until complete assembly of linear particles with a final length of $34 \pm 3 \%$ of the initial length ( $N=25$ DNA molecules at each concentration) (Fig. 1d). Total DNA contraction to about one third of the DNA original length has also been observed by previous AFM studies $^{1}$. Concentrations between $10 \mathrm{nM}$ and $50 \mathrm{nM}$ decreased the DNA encapsidation rate (measured as thalf, the time required to achieve half of total packaging) and did not completely contract the DNA to its final encapsulated length, suggesting limited $\mathrm{C}-\mathrm{S}_{10}-\mathrm{B}$ binding. Initial condensation rate increased with polypeptide concentration in a sigmoid-shaped curve distinctive of nucleated self-assemblies (Fig. 1e). Nucleation and particle growth were significantly impaired at $25 \mathrm{nM} \mathrm{C}$ $\mathrm{S}_{10}$-B compared with $150 \mathrm{nM}$ (Fig. S2). These results are consistent 
bioRxiv preprint doi: https://doi.org/10.1101/2020.10.17.343996; this version posted October 23, 2020. The copyright holder for this preprint (which was not certified by peer review) is the author/funder, who has granted bioRxiv a license to display the preprint in perpetuity. It is made available under aCC-BY-NC-ND 4.0 International license.

Calcines-Cruz et al., 13 oct. 2020 - preprint copy - BioRxiv

with a dynamic equilibrium between $\mathrm{C}-\mathrm{S}_{10}-\mathrm{B}$ nucleation-filamentation and dissociation from DNA, akin to RAD51 and other dynamic filaments ${ }^{26}$.

a

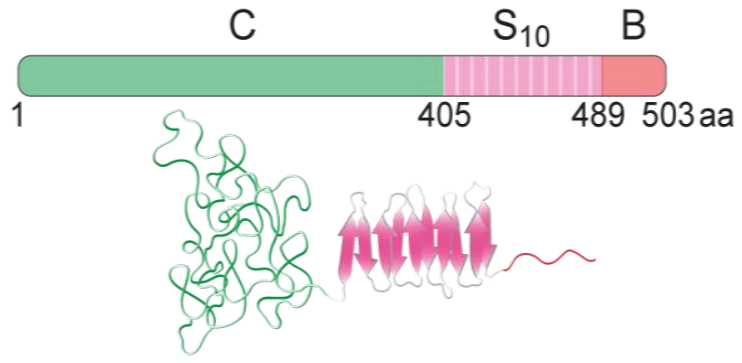

b

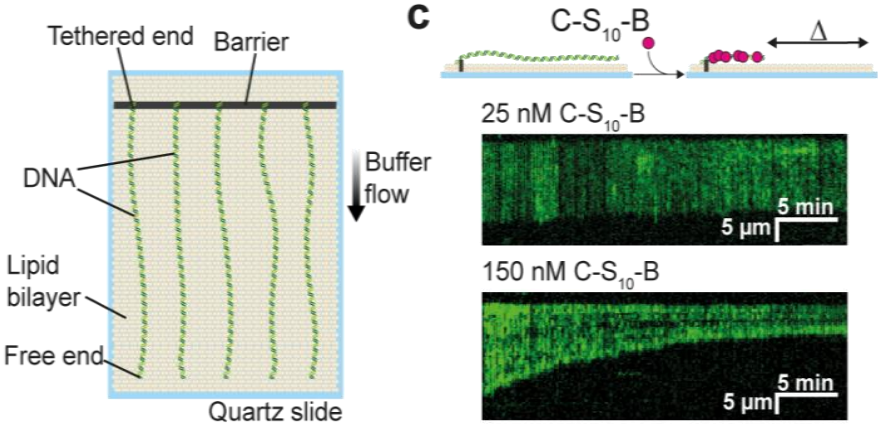

d

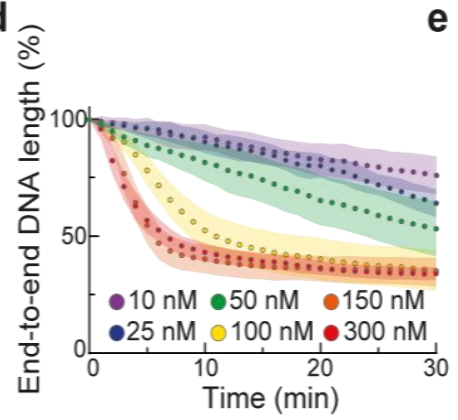

e

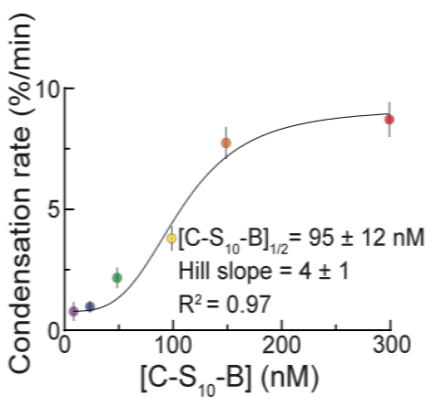

Fig. 1: The synthetic polypeptide $C-S_{10}-B$ packages DNA into nucleocapsids via molecular self-assembly. a: Schematic depiction and modular design of $\mathrm{C}-\mathrm{S}_{10}-\mathrm{B}$. $\mathbf{b}$ : Illustration of the DNA curtain assay. Individual DNA molecules are captured on the surface of a lipid-coated flowcell and extended by gentle buffer flow. c: Representative kymographs showing condensation of individual DNA strands (green) at different rates determined by $\mathrm{C}-\mathrm{S}_{10}-\mathrm{B}$ concentration. The DNA is stained with the intercalating dye YOYO-1. d: DNA condensation profiles at the indicated $\mathrm{C}-\mathrm{S}_{10}-\mathrm{B}$ concentrations. The circles and shaded areas represent the mean and standard deviation for 25 molecules per condition, respectively. e: DNA condensation rate in the first $3 \mathrm{~min}$ of assembly at different concentrations of $\mathrm{C}-\mathrm{S}_{10}-\mathrm{B}$. The data were fitted to a sigmoid (solid line) and shown are mean $\pm 95 \%$ confidence intervals for 25 DNA molecules per condition.

Next, we evaluated whether positioning dCas12a on the DNA can improve encapsidation at low $\mathrm{C}-\mathrm{S}_{10}-\mathrm{B}$ concentrations. The DNA was uniformly decorated with five or ten dCas12a-crRNA ribonucleoproteins (RNPs) (Fig. 2a). We confirmed site-specific target binding by imaging fluorescent RNPs along the DNA molecule (Fig. S3a). We observed from 1 to $4(1.2 \pm 0.5$ RNP per DNA) target-bound RNPs on DNA substrates harboring five binding sites $(\mathrm{N}=456 \mathrm{DNA}$ molecules $)$ and 1 to 7 RNPs $(2.6 \pm 1.1$ RNP per DNA) on DNA substrates with ten binding sites ( $\mathrm{N}=185$ DNA molecules) (Fig. S3b). Because not all RNPs are decorated with fluorescent QDs, our results are a lower bound on the true target site occupancy. To monitor how encapsidation varies with RNP density, we injected $25 \mathrm{nM} \mathrm{C-S} 10-\mathrm{B}$ into curtains with DNA strands pre-decorated with either five or ten RNPs (Figs. 2b-c). DNA contraction rate increased two- and three-fold for DNA decorated with five ( $t_{\text {half }}=15 \pm 7 \mathrm{~min} ; \mathrm{N}=25$ DNA molecules) or ten ( $t_{\text {half }}=10 \pm 3 \mathrm{~min} ; \mathrm{N}=25$ ) RNPs with respect to naked DNA ( $\mathrm{t}_{\text {half }}=$ $31 \pm 6$ min; $N=25$ ) (Fig. 2d). We conclude that dCas12a RNPs can be installed at specific sites along the DNA template and that such decoration promotes and accelerates encapsidation by $\mathrm{C}-\mathrm{S}_{10}-\mathrm{B}$.

We reasoned that $\mathrm{dCas} 12 \mathrm{a}$ organizes large $\mathrm{C}-\mathrm{S}_{10}-\mathrm{B}$ clusters that further polymerize into filaments. Two-color imaging confirmed that fluorescent $\mathrm{C}-\mathrm{S}_{10}-\mathrm{B}$ co-localizes with the RNPs at early stages of encapsidation (Fig. 2e). Positioning five RNPs on the DNA increased the number of fluorescent $\mathrm{C}-\mathrm{S}_{10}-\mathrm{B}$ puncta per DNA strand from 1-3 (1.3 $\pm 0.6, \mathrm{~N}=166$ DNA molecules $)$ to $2-7(3.3 \pm 1.0, \mathrm{~N}=97 \mathrm{DNA}$ molecules) for naked and dCas12a-decorated DNA, respectively (Fig. $2 \mathrm{f})$. $\mathrm{C}-\mathrm{S}_{10}-\mathrm{B}$ protomers can freely diffuse on the DNA ${ }^{27}$. In the presence of buffer flow, these molecules slide and assemble into large clusters at the free DNA ends. In contrast, $\mathrm{C}-\mathrm{S}_{10}-\mathrm{B}$ accumulated at dCas $12 \mathrm{a}$ sites on the decorated DNA (Fig. S3c). Filament growth was also more rapid on pre-decorated DNA substrates (thalf $=15 \pm 6 \mathrm{~min} ; \mathrm{N}=10$ DNA molecules) than on naked DNA (thalf $=45 \pm 15 \mathrm{~min} ; \mathrm{N}=10$ DNA molecules) (Fig. $2 \mathrm{~g}$ ). C-S $\mathrm{S}_{10} \mathrm{~B}$ filamentation was unable to displace dCas12a, which forms a stable RNA:DNA loop (R-loop) with the DNA substrate (Fig. S3d). Because dCas12a may act as a roadblock for C$\mathrm{S}_{10}$-B linear diffusion on the DNA, we also tested whether other DNAbinding proteins will also accumulate $\mathrm{C}-\mathrm{S}_{10}-\mathrm{B}$ clusters. Notably, DNA decoration with nucleosomes also accelerated DNA encapsidation and particle growth (Fig. S4). We conclude that dCas12a stalls $\mathrm{C}-\mathrm{S}_{10}-\mathrm{B}$ sliding on DNA, which enhances polypeptide collisions in its vicinity and triggers particle nucleation. In support of this model, Marchetti et al. ${ }^{27}$ observed that immobile $\mathrm{C}-\mathrm{S}_{10}-\mathrm{B}$ clusters, and not their sliding counterparts, initiate filament growth.

To further promote and accelerate DNA packaging at limiting $\mathrm{C}-\mathrm{S}_{10}-\mathrm{B}$ concentrations, we physically coupled dCas12a to the di-block polypeptide $\mathrm{C}_{-} \mathrm{S}_{10}$ via the rapamycin-inducible FKBP and FRB dimerization domains (Fig. 3a). We cloned and purified a dCas12a $\mathrm{a}_{(\mathrm{FKBP})}$ $\mathrm{C}$-terminal fusion and verified that this construct retains target-specific DNA binding (Fig. S1). The FRB domain was fused to a truncated C$S_{10}$ polypeptide that lacks the "B" DNA-binding module. Both proteins,

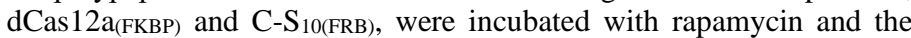
dimerized complex was injected into the flowcell prior to incubation with $10 \mathrm{nM}$ C-S10-B (Fig. 3b-c, Fig. S5). Positioning five dimerized dCas12a-S $\mathrm{S}_{10}$ complexes along the DNA substrate accelerated encapsidation by $\mathrm{C}-\mathrm{S}_{10}$-B two-fold relative to dCas $12 \mathrm{a}_{\text {(FKBP) }} \mathrm{RNP}$ alone (thalf $=9 \pm 3 \mathrm{~min} ; \mathrm{N}=25$ vs. $18 \pm 6 \mathrm{~min} ; \mathrm{N}=25$ ), and five-fold relative to the undecorated DNA (thalf $=46 \pm 13 \mathrm{~min} ; \mathrm{N}=25$ ) (mean $\pm \mathrm{SD}$, Fig. 3d-e). We confirmed this result via ensemble biochemical electrophoretic mobility shift assays (EMSAs) (Fig. S6). Positioning the dCas12a-S $\mathrm{S}_{10}$ complex on a $2.5 \mathrm{kbp}$ linear dsDNA or a $9.5 \mathrm{kbp}$ plasmid dsDNA also improved encapsidation at limiting $\mathrm{C}-\mathrm{S}_{10}-\mathrm{B}$ concentrations (Fig. S6). These results indicate that initiating nucleation via interspersed dCas12a RNPs fused to the self-assembly domain $\mathrm{S}_{10}$ accelerates DNA packaging at sub-saturating $\mathrm{C}-\mathrm{S}_{10}-\mathrm{B}$ concentrations. 
bioRxiv preprint doi: https://doi.org/10.1101/2020.10.17.343996; this version posted October 23, 2020. The copyright holder for this preprint (which was not certified by peer review) is the author/funder, who has granted bioRxiv a license to display the preprint in perpetuity. It is made available under aCC-BY-NC-ND 4.0 International license.

Calcines-Cruz et al., 13 oct. 2020 - preprint copy - BioRxiv

a

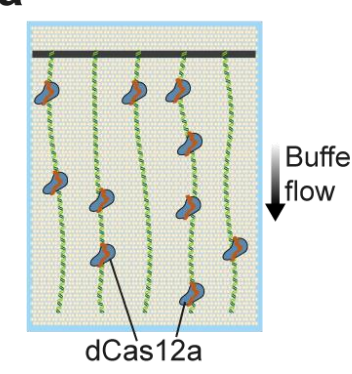

b

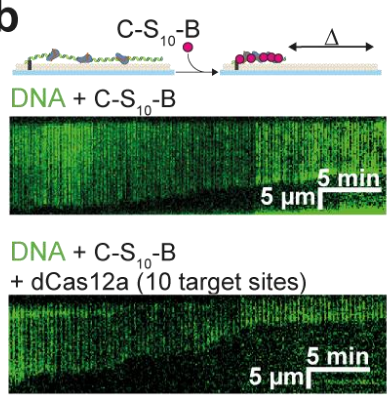

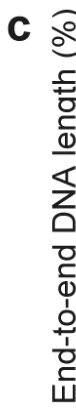

d

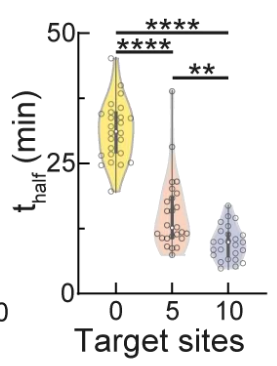

e

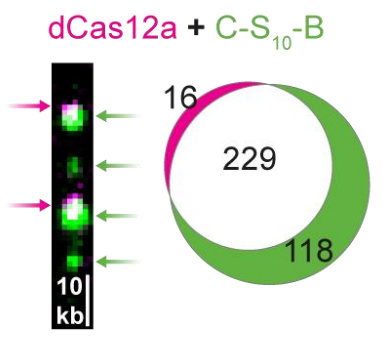

f

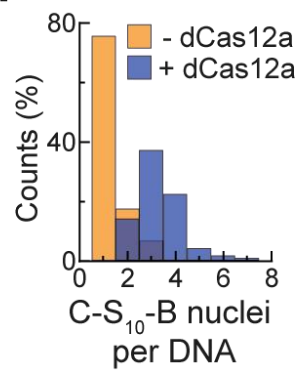

g

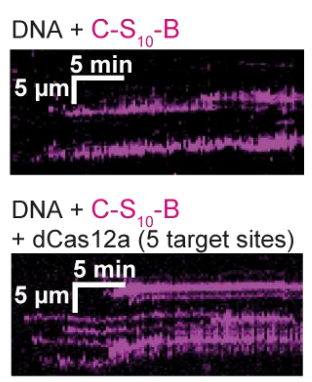

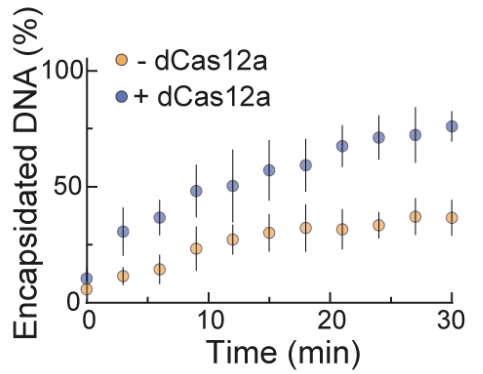

Fig. 2: Seeding assembly with dCas12a improves DNA encapsidation by $\mathbf{C}-\mathbf{S}_{10}-\mathbf{B}$. a: Illustration of a dCas12a-decorated DNA substrates. dCas $12 a$ is incubated with pools of crRNAs and directed to 5 or 10 sites uniformly distributed along the DNA prior to C-S ${ }_{10}-\mathrm{B}$ injection. $\mathbf{b}$ : Representative kymographs show faster encapsidation at $25 \mathrm{nM} \mathrm{C}-\mathrm{S}_{10}-\mathrm{B}$ after the DNA (green) is decorated with dCas12a. c: Condensation profiles at $25 \mathrm{nM} \mathrm{C}-\mathrm{S}_{10}-\mathrm{B}$ for naked DNA, and DNA decorated with dCas12a targeting 5 or 10 sequences along the template. The circles and shaded areas represent the mean and standard deviation for 25 molecules per condition, respectively. d: Violin plots showing the time (thalf) required to reach half of maximum condensation for each DNA molecule analyzed in (c). For zero target sites, we fitted the curve to a sigmoid and extrapolated thalf for molecules that did not reach $65.5 \%$ encapsidation during the experiment $\left.(30 \mathrm{~min}) .{ }^{* *}\right)$ and $\left(^{* * * *}\right)$ indicate $p<0.01$ and $p<0.0001$, respectively. e: Fluorescent dCas $12 a$ (magenta, 93\%) co-localizes with fluorescent $\mathrm{C}-\mathrm{S}_{10}$-B clusters (green, 66\%). f: Positioning five dCas12a molecules on the DNA increases the number of fluorescent $C-S_{10}-B$ clusters relative to undecorated DNA ( $N=484$ and 246 clusters, respectively). g: Kymographs showing $C-S_{10}-B$ binding (magenta) on undecorated (top) or dCas12a-decorated (bottom) DNA and percentage of the DNA strand length that is encapsidated by the fluorescent $\mathrm{C}$ - $\mathrm{S}_{10}-\mathrm{B}$. Shown are the mean standard deviation for 10 molecules per condition.

Finally, we assessed whether targeting dCas12a-S 10 to a specific DNA template can trigger VLP encapsidation in the presence of other (noncognate) DNA molecules. For this assay, we immobilized an equimolar mixture of two DNA templates on the flowcell surface; one was $20 \mathrm{kbp}$ and the second was $28.5 \mathrm{kbp}$ (Fig. $4 \mathrm{a}$ ). dCas12a-S 10 was directed to 5 , 10 or 25 sites on the $28.5 \mathrm{kbp}$ template (Fig. 4b). As seen in Fig. 4c-d and Fig. S7, dCas12a-S 10 selectively accelerated the packaging of the target DNA template and the encapsidation rate increased three-fold from zero target sites ( $t_{\text {half }}=62 \pm 26 \mathrm{~min} ; \mathrm{N}=25$ ) to a maximum of 25 target sites $\left(t_{\text {half }}=19 \pm 6 \mathrm{~min} ; \mathrm{N}=25\right)$.

\section{Discussion}

Taken together, our data show that a target DNA-bound dCas12a (or any strongly DNA-bound roadblock protein) can serve as a viral-like packaging signal during the self-assembly of VLPs - especially if the roadblock protein contains a self-assembly or polymerization domain. RNA-guided CRISPR-Cas proteins are especially attractive as artificial packaging signals because they can be targeted to any DNA sequence that is proximal to a protospacer adjacent motif (PAM). For AsdCas12a, the PAM consensus sequence is TTTV; this PAM appears on average every $32 \mathrm{bp}$ on $48.5 \mathrm{kbp}$ long $\lambda$-phage DNA. Other CRISPR-Cas enzymes, including Cas9, can also serve as nucleation signals. Relaxed PAM variants, both for Cas9 and Cas12, will further increase the targeting possibilities for rapid and sequence specific VLP assembly ${ }^{28-}$ 31. Additionally, this work shows that $\mathrm{C}-\mathrm{S}_{10}-\mathrm{B}$ protein can be reengineered to more closely resemble virus-like features.

In summary, we have used CRISPR-dCas12a protein and coupled it to the polymerization domain $S_{10}$ to form a "packaging-signal recognition complex" (in analogy with the assembly of viral capsid proteins around the viral genome) that triggers binding of $\mathrm{C}-\mathrm{S}_{10}-\mathrm{B}$ and packaging of target DNA sequences. Importantly, such packaging recognition complex (and hence artificial particle nucleation and growth) can be easily redirected toward different DNA sequences by simple design of the crRNA without need of the more cumbersome manipulation of protein domains. Moreover, our results highlight the importance of having multiple strong and specific interactions in templated nucleoprotein self-assemblies and should prove useful for developing new tailor-made nanomaterials for diverse biotechnological applications. 
bioRxiv preprint doi: https://doi.org/10.1101/2020.10.17.343996; this version posted October 23, 2020. The copyright holder for this preprint (which was not certified by peer review) is the author/funder, who has granted bioRxiv a license to display the preprint in perpetuity. It is made available under aCC-BY-NC-ND 4.0 International license.

Calcines-Cruz et al., 13 oct. 2020 - preprint copy - BioRxiv

a
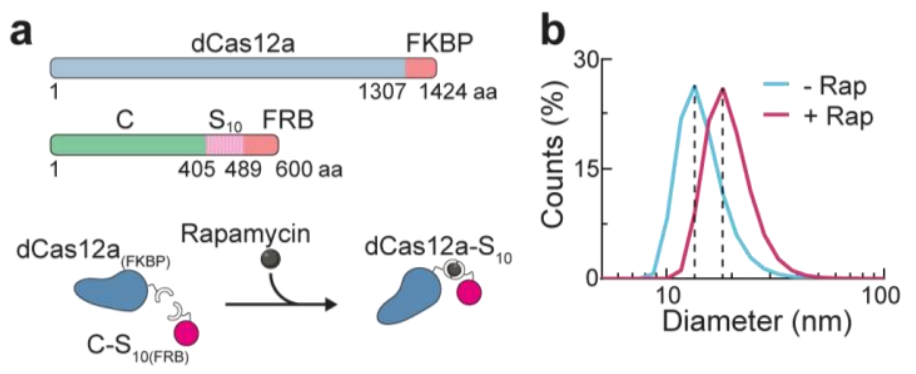

C
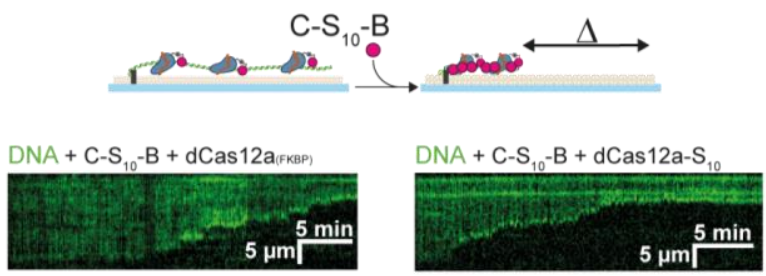

d
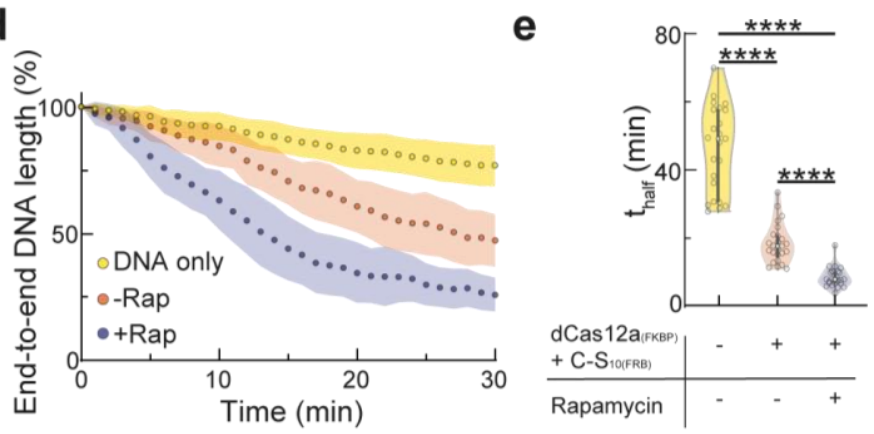

Fig. 3. Coupling of dCas12a to the self-assembly domain $C-S_{10}$ improves $\mathrm{C}-\mathrm{S}_{10}-\mathrm{B}$ nucleation and assembly. a: Schematic depiction of the modular design of $\mathrm{dCas} 12 \mathrm{a}_{(\mathrm{FKBP})}$ and $\mathrm{C}-\mathrm{S}_{10(\mathrm{FRB})}$ and their dimerization via rapamycin to form the dCas $12 a-S_{10}$ complex. b: Dynamic light scattering experiment showing rapamycin (Rap) induced dimerization of $\mathrm{dCas} 12 \mathrm{a}_{\text {(FKBP) }}$ and $\mathrm{C}-\mathrm{S}_{10(\mathrm{FRB})}$. The shift in population size occurred immediately after rapamycin addition. c: Representative kymographs showing that decorating DNA with dCas $12 \mathrm{a}-\mathrm{S}_{10}$ accelerates DNA packaging at $10 \mathrm{nM} \mathrm{C}-\mathrm{S}_{10}-\mathrm{B}$ relative to decoration with dCas $12 \mathrm{a}_{(\mathrm{FKBP})}$ alone. d: Condensation profiles at 10 $\mathrm{nM} \mathrm{C}-\mathrm{S}_{10}-\mathrm{B}$ for undecorated DNA, and DNA decorated with 5 $\mathrm{dCas} 12 \mathrm{a}_{(\mathrm{FKBP})}$ or $5 \mathrm{dCas} 12 \mathrm{a}-\mathrm{S}_{10}$. The circles and shaded areas represent the mean and standard deviation for 25 molecules per condition, respectively. e: Violin plots showing the time ( $\left.t_{\text {half }}\right)$ required to reach half of maximum condensation for each DNA strand analyzed in (d). Extrapolation (after sigmoid curve fitting) was used to estimate thalf for molecules that did not reach $65.5 \%$ encapsidation during the experiment $\left.(30 \mathrm{~min}) .{ }^{* * * *}\right)$ indicates $p<0.0001$.
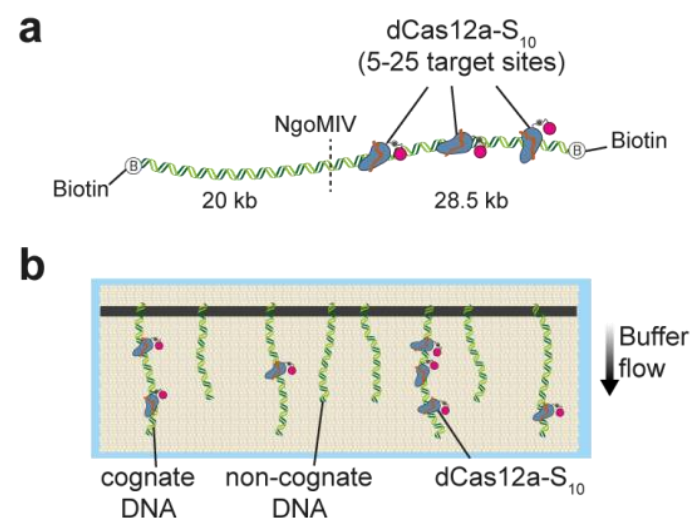

C
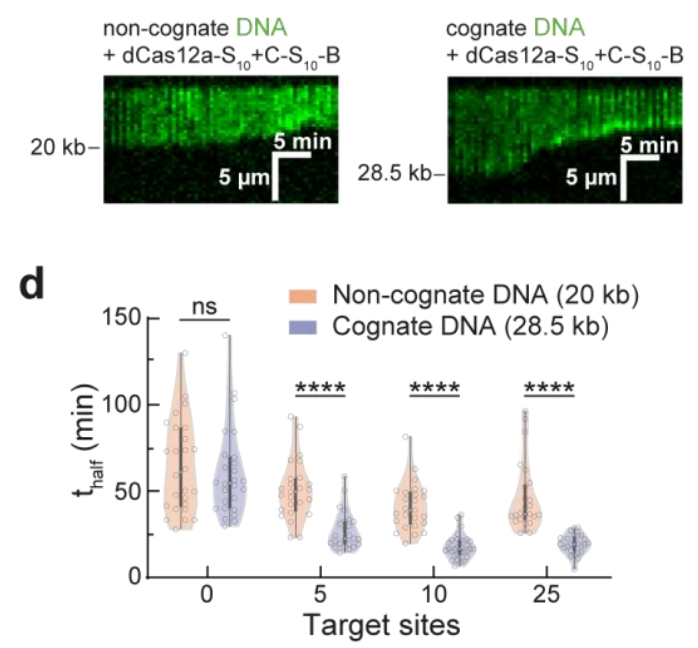

Fig. 4. $C-S_{10}-B$ selectively assembles on DNA that is decorated with dCas12a-S ${ }_{10}$. a: DNA was ligated with biotinylated oligos at both ends followed by cleavage with NgoMIV to generate two biotinylated DNA substrates (20 kbp and $28.5 \mathrm{kbp}$ ) distinguishable by size after YOYO-1 staining. $\mathbf{b}$ : The $28 \mathrm{kbp}$ DNA (cognate DNA) was decorated

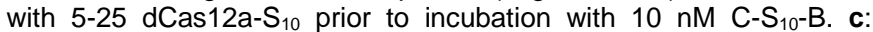
Representative kymographs showing encapsidation of the noncognate $(20 \mathrm{kbp})$ and cognate $(28.5 \mathrm{kbp})$ DNA after decoration with 10 dCas $12 a-S_{10}$. d: Violin plots showing the time $\left(t_{\text {half }}\right)$ required to reach half of maximum condensation for cognate and non-cognate DNA strands after decoration with 0-25 dCas $12 a-S_{10}$. We estimate (after sigmoid curve fitting) $t_{\text {half }}$ for molecules that did not reach $65.5 \%$ encapsidation during the experiment $(30 \mathrm{~min}) .\left({ }^{* * *}\right)$ indicates $\mathrm{p}<$ 0.0001 . 
bioRxiv preprint doi: https://doi.org/10.1101/2020.10.17.343996; this version posted October 23, 2020. The copyright holder for this preprint (which was not certified by peer review) is the author/funder, who has granted bioRxiv a license to display the preprint in perpetuity. It is made available under aCC-BY-NC-ND 4.0 International license.

Calcines-Cruz et al., 13 oct. 2020 - preprint copy - BioRxiv

\section{Materials and Methods}

\section{Plasmids, protein expression and purification}

The FK506 Binding Protein (FKBP) and FKBP-Rapamycin Binding domain (FRB) sequences were extracted from pGEX-2T plasmids (kindly provided by Tom Wandless, Stanford University) and inserted at the Cterminus of nuclease inactivated version of AsCas12a (D908A) and C$\mathrm{S}_{10}$, respectively.

The $\mathrm{pET} 19$ plasmids with $\mathrm{dCas} 12 \mathrm{a}$ and $\mathrm{dCas} 12 \mathrm{a}_{\text {(FKBP) }}$ (both with an $\mathrm{N}$ terminus 6XHis-SUMO tag) were used to transform BL21 (DE3) Escherichia coli. Colonies were grown on Luria Bertani plates with 100 $\mu \mathrm{g} / \mathrm{mL}$ ampicillin and used to inoculate Terrific Broth liquid culture in Fernbach flasks. Cultures were grown at $37^{\circ} \mathrm{C}$ until $\mathrm{OD}_{60} \sim 0.8$ and then transferred to $12^{\circ} \mathrm{C}$ for $1 \mathrm{~h}$ before induction with $1 \mathrm{mM}$ IPTG. Cultures were then grown for $24 \mathrm{~h}$ at $12^{\circ} \mathrm{C}$ and the pellets were collected by centrifugation and stored at $-70^{\circ} \mathrm{C}$.

The pellets were resuspended in buffer A $(20 \mathrm{mM}$ Tris- $\mathrm{HCl}$ pH 8.0, 250 $\mathrm{mM} \mathrm{NaCl}, 10 \mathrm{mM}$ imidazole) supplemented with $1 \mathrm{mM}$ PMSF and sonicated on ice. The lysate was clarified by centrifugation at $30000 \mathrm{~g}$ for $45 \mathrm{~min}$ and the supernatant containing the protein of interest was filtered through $0.2 \mu \mathrm{m}$ syringe filters. The supernatant was then loaded into a 5 $\mathrm{mL}$ HisTrap (GE Healthcare) column, washed with buffer B $(20 \mathrm{mM}$ Tris$\mathrm{HCl} \mathrm{pH} \mathrm{8.0,1} \mathrm{M} \mathrm{NaCl,} 25 \mathrm{mM}$ imidazole) and eluted with buffer C (20 mM Tris- $\mathrm{HCl} \mathrm{pH} 8.0,1 \mathrm{M} \mathrm{NaCl}, 250 \mathrm{mM}$ imidazole). The eluted fraction was loaded into a dialysis membrane with $2.4 \mu \mathrm{M}$ SUMO protease and dialyzed overnight at $4^{\circ} \mathrm{C}$ in buffer $\mathrm{D}$ for dCas $12 \mathrm{a}(50 \mathrm{mM}$ phosphate buffer $\mathrm{pH} 6.0,100 \mathrm{mM} \mathrm{KCl}, 5 \mathrm{mM} \mathrm{MgCl}, 10 \%$ glycerol, $2 \mathrm{mM}$ DTT) and buffer $\mathrm{E}$ for dCas12a $\mathrm{a}_{\text {(FKBP) }}$ (20 mM HEPES-KOH pH 7.2, $100 \mathrm{mM} \mathrm{KCl}, 5$ $\mathrm{mM} \mathrm{MgCl}, 10 \%$ glycerol, $2 \mathrm{mM}$ DTT). The $0.2 \mu \mathrm{m}$ filtered cleaved product was injected in a $5 \mathrm{~mL}$ HiTrap SP HP (GE Healthcare) cationic exchange column and eluted with a gradient to buffer $F$ (20 mM HEPES$\mathrm{KOH} \mathrm{pH} 7.5,2 \mathrm{M} \mathrm{KCl}$ ). The fractions containing the protein of interest were pooled, concentrated with $100 \mathrm{kDa}$ Amicon centrifugal filter units and injected into a size exclusion HiLoad 16/600 Superdex 200 pg column (GE Healthcare) equilibrated with storage buffer $\mathrm{G}(20 \mathrm{mM}$ HEPES-KOH pH 7.5, $500 \mathrm{mM} \mathrm{KCl}, 10 \%$ glycerol). Purified proteins were concentrated to $10-12 \mu \mathrm{M}$, flash frozen in liquid nitrogen and stored at $70^{\circ} \mathrm{C}$ until use. Protein identity and purity were assessed with western blots and SDS-PAGE, respectively.

pPIC9 plasmids with $\mathrm{C}-\mathrm{S}_{10}-\mathrm{B}$ and $\mathrm{C}-\mathrm{S}_{10(\mathrm{FRB})}$ were linearized with $\mathrm{Sacl}$ and electroporated into histidine auxotrophic Pichia pastoris GS115. Mut ${ }^{+}$ colonies expressing the protein were used to inoculate $300 \mathrm{~mL}$ of MGY and grown for $24 \mathrm{~h}$ until $\mathrm{OD}_{600} \sim 6.0$. Cells were pelleted and resuspended in MM medium for protein expression for $72 \mathrm{~h}$, with $1 \%$ methanol addition every $24 \mathrm{~h}$. Culture supernatant was collected by centrifugation, the medium $\mathrm{pH}$ was adjusted to 8.0 with $\mathrm{NaOH}$ and $1 \mathrm{mM}$ PMSF and $5 \mathrm{mM}$ EDTA were added to inhibit proteolysis followed by $0.2 \mu \mathrm{m}$ filtration.

For $\mathrm{C}-\mathrm{S}_{10} \mathrm{~B}$, the culture supernatant was then saturated to $50 \%$ with ammonium sulfate and incubated overnight at $4^{\circ} \mathrm{C}$. The protein precipitate was resuspended in Milli-Q water at $65^{\circ} \mathrm{C}$ and the precipitation step was repeated once. The precipitate was resuspended in Milli-Q water at $65^{\circ} \mathrm{C}$ before $50 \mathrm{mM} \mathrm{NaCl}$ and $40 \%$ acetone addition. The sample was centrifuged to discard precipitates and the concentration of acetone in the supernatant was increased to $80 \%$ to selectively precipitate $\mathrm{C}_{\mathrm{S}} \mathrm{S}_{10}-\mathrm{B}$. The precipitate was air dried for $15 \mathrm{~min}$, resuspended and dialyzed overnight against Milli-Q water at $4^{\circ} \mathrm{C}$, followed by flash freeze and lyophilization. Before use, the lyophilized protein was dissolved in Milli-Q water at $0.1 \mathrm{mg} / \mathrm{mL}$ and incubated at $70^{\circ} \mathrm{C}$ for $15 \mathrm{~min}$.

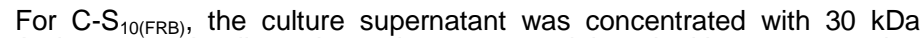
Amicon stirred cells and proteins were precipitated with $80 \%$ saturation ammonium sulfate at $4^{\circ} \mathrm{C}$ overnight. The protein precipitate was resuspended in PBS pH 7.5 and the precipitation step was repeated once. The precipitate was resuspended in PBS pH 7.5 and $40 \%$ acetone was added followed by centrifugation. The concentration of acetone in the supernatant was increased to $80 \%$ to selectively precipitate $\mathrm{C}-\mathrm{S}_{10(\mathrm{FRB})}$. The precipitate was resuspended to $\sim 80 \mu \mathrm{M}$ in PBS $\mathrm{pH} 7.5$, dialyzed overnight against PBS $\mathrm{pH} 7.5$ at $4^{\circ} \mathrm{C}$ and flash frozen. Protein identity and purity were assessed with mass spectrometry and SDS-PAGE, respectively.

\section{crRNA pools}

The $24 \mathrm{nt}$ forward oligo with the promoter for T7 RNA polymerase, and the $68 \mathrm{nt}$ reverse oligos with the $24 \mathrm{nt}$ sequence complementary to the forward oligo plus the $44 \mathrm{nt}$ crRNA sequence were purchased from IDT. The T7 promoter forward oligo was mixed with pools of reverse oligos (1.5:1.0 molar ratio) and hybridized by incubation at $75^{\circ} \mathrm{C}$ for 5 min and then cooling to $25^{\circ} \mathrm{C}$ over $25 \mathrm{~min}$ in annealing buffer $(10 \mathrm{mM}$ Tris- $\mathrm{HCl} \mathrm{pH}$ 7.5, $50 \mathrm{mM} \mathrm{NaCl}, 1 \mathrm{mM}$ EDTA). The pool of partially double stranded
DNA templates was used for in vitro transcription with HiScribe ${ }^{\mathrm{TM}} \mathrm{T7}$ Quick High Yield RNA Synthesis Kit (New England BioLabs) and the RNA was purified with TRizol (Ambion). crRNA integrity and purity were assessed with $15 \%$ acrylamide Urea-PAGE.

\section{Preparation of DNA substrates}

To prepare the DNA template for curtain assays $\lambda$ DNA $(125 \mu \mathrm{g}, \mathrm{NEB})$ was incubated with $2 \mu \mathrm{M}$ biotinylated oligo complementary to one of the two $12 \mathrm{nt}$ cohesive ends in ADNA in T4 DNA ligase reaction buffer (NEB) and hybridized at $70^{\circ} \mathrm{C}$ for $15 \mathrm{~min}$ followed by cooling to $15^{\circ} \mathrm{C}$ over $2 \mathrm{~h}$. T4 DNA ligase (2000 units, NEB) was added and the mixture was incubated at room temperature overnight. The ligase was inactivated with $2 \mathrm{M} \mathrm{NaCl}$ and the sample was injected into a Sephacryl S-1000 size exclusion column (GE Healthcare) to remove excess oligos and DNA ligase.

For experiments with nucleosomal DNA, purified biotinylated DNA was precipitated with sodium acetate $(\mathrm{pH} 5.5)$ and $0.3 \mathrm{M}$ isopropanol to $1: 1$ $\mathrm{v} / \mathrm{v}$ on ice, and centrifuged at $15000 \mathrm{~g}$ for $30 \mathrm{~min}$. The precipitate was resuspended to $0.8 \mathrm{nM}$ and incubated with human histone octamers (3xHA H2A and H2B, H3, H4; Histone Source) at molar ratios of $50: 1$ and $100: 1$ (histone octamer to $\lambda$ DNA) in $2 \mathrm{M}$ TE buffer $(10 \mathrm{mM}$ Tris- $\mathrm{HCl} \mathrm{pH} 8$ $1 \mathrm{mM}$ EDTA, $2 \mathrm{M} \mathrm{NaCl}$ ) with $1 \mathrm{mM}$ DTT. The $100 \mu \mathrm{L}$ mixture was loaded in dialysis buttons (10 kDa MWCO, BioRad) and dialyzed against dialysis buffer (10 mM Tri-HCl pH 7.6, $1 \mathrm{mM}$ EDTA, $1 \mathrm{mM}$ DTT and $\mathrm{NaCl})$. The first $1 \mathrm{~h}$ dialysis step was done against $1.5 \mathrm{M} \mathrm{NaCl}$, followed by $2 \mathrm{~h}$ dialysis steps against $1,0.8,0.6$ and $0.4 \mathrm{mM}$ with a final overnight step against $0.2 \mathrm{M} \mathrm{NaCl}$ at $4^{\circ} \mathrm{C}$.

For experiments with two DNA strands, ADNA was ligated with biotinylated oligos complementary to both cohesive ends. Hybridization and ligation were performed as described above except that CutSmart buffer (NEB) supplemented with $1 \mathrm{mM}$ rATP was used instead of T4 ligase buffer. The mixture was heated at $65^{\circ} \mathrm{C}$ for $10 \mathrm{~min}$ to inactivate the ligase and NgoMIV was added for DNA cleavage at $37^{\circ} \mathrm{C}$ for $3 \mathrm{~h}$. Lastly, $2 \mathrm{M} \mathrm{NaCl}$ was added to the solution prior to size exclusion chromatography. Complete cleavage by NgoMIV was assessed with gel electrophoresis. All DNA substrates were stored at $4^{\circ} \mathrm{C}$ until use.

\section{Single-tethered DNA curtain assay}

A solution containing $20 \mu \mathrm{L}$ of a liposome stock solution (97.7\% DOPC, $2.0 \%$ DOPE-mPEG2k and $0.3 \%$ DOPE-biotin) and $980 \mu \mathrm{L}$ of lipid buffer $(10 \mathrm{mM}$ Tris-HCL pH 8, $100 \mathrm{mM} \mathrm{NaCl}$ ) was injected into the assembled flowcell and incubated for $30 \mathrm{~min}$ at room temperature. The flowcell was washed with BSA buffer ( $40 \mathrm{mM}$ Tris- $\mathrm{HCl} \mathrm{pH} 8,2 \mathrm{mM} \mathrm{MgCl}, 0.2 \mathrm{mg} / \mathrm{mL}$ BSA) and incubated for 10 min before injection of $0.1 \mathrm{mg} / \mathrm{mL}$ streptavidin in BSA buffer followed by 10 min incubation. The biotinylated $\lambda$ DNA was diluted in BSA buffer and injected into the flowcell for tethering, excess DNA was removed with buffer. Imaging buffer consisted of BSA buffer supplemented with $100 \mathrm{mM} \mathrm{NaCl}, 5 \mathrm{mM} \mathrm{MgCl} 2,2 \mathrm{mM}$ DTT and gloxy solution (500 units of catalase, 70 units of glucose oxidase and $1 \%$ glucose $w / v)$. YOYO-1 was added to the imaging buffer when DNA staining was required.

Total internal reflection fluorescence images were acquired with an inverted Nikon Ti-E microscope. Excitation (488 nM) and emission signals were split with a $638 \mathrm{~nm}$ dichroic beam splitter (Chroma) and captured by two EM-CCD cameras (Andor iXon DU897). Images were processed with FIJI software.

$\mathrm{dCas} 12 \mathrm{a}$ or $\mathrm{dCas} 12 \mathrm{a}_{(\mathrm{FKBP})}$ ribonucleoprotein complexes were prepared by mixing the protein with crRNA pools at $1: 10$ molar ratio in reaction buffer (20 mM Tris- $\mathrm{HCl} \mathrm{pH} 8.0,100 \mathrm{mM} \mathrm{NaCl}, 5 \mathrm{mM} \mathrm{MgCl}$, $2 \%$ glycerol, $2 \mathrm{mM}$ DTT) followed by incubation at $37^{\circ} \mathrm{C}$ for $30 \mathrm{~min}$. The complexes were diluted to $10 \mathrm{nM}$ in imaging buffer, injected in the flowcell and incubated at room temperature for $30 \mathrm{~min}$.

Labeling of dCas $12 \mathrm{a}$ and nucleosomes was carried out in situ by injection into the flowcell of anti-FLAG or anti-HA coupled quantum dots $\left(\mathrm{QD}_{705}\right)$, respectively. $C-S_{10}-B$ and $C-S_{10(F R B)}$ were labeled via maleimide reaction with Alexa488 and Atto647N, respectively. Both C-S ${ }_{10}-\mathrm{B}$ and C-S $\mathrm{S}_{10 \text { (FRB }}$ contain an N-terminal cysteine residue and $\mathrm{C}-\mathrm{S}_{10 \text { (FRB) }}$ has an additional cysteine in the FRB moiety.

\section{Dynamic light scattering}

Dimerization of $d$ Cas $12 \mathrm{a}_{\text {(FKBP) }}$ and C-S $\mathrm{S}_{10(\mathrm{FRB})}$ via rapamycin was assessed by dynamic light scattering with a Zetasizer $\mu \mathrm{V}$ (Malvern). Both proteins were diluted to $2 \mu \mathrm{M}$ in reaction buffer $(20 \mathrm{mM}$ Tris-HCl pH 8.0, $100 \mathrm{mM}$ $\mathrm{NaCl}, 5 \mathrm{mM} \mathrm{MgCl}, 2 \%$ glycerol, $1 \mathrm{mM}$ DTT) for a total volume of $20 \mu \mathrm{L}$ and loaded in the cell. Measurements were taken before and immediately after ( $30 \mathrm{~s})$ addition of $5 \mu \mathrm{M}$ rapamycin. 
bioRxiv preprint doi: https://doi.org/10.1101/2020.10.17.343996; this version posted October 23, 2020. The copyright holder for this preprint (which was not certified by peer review) is the author/funder, who has granted bioRxiv a license to display the preprint in perpetuity. It is made available under aCC-BY-NC-ND 4.0 International license.

Calcines-Cruz et al., 13 oct. 2020 - preprint copy - BioRxiv

\section{Electrophoretic mobility shift assay}

The crRNA-loaded dCas12a- $S_{10}$ complex was incubated with $100 \mathrm{ng}$ DNA (linear or plasmid) for $1 \mathrm{~h}$ before $\mathrm{C}-\mathrm{S}_{10}-\mathrm{B}$ addition at stoichiometry ratios ([C-S $\left.{ }_{10}-\mathrm{B}\right]:[\mathrm{DNA}$ binding sites], N/P) from 0 to 3 . Encapsidation was assessed on agarose gel electrophoresis at $4^{\circ} \mathrm{C}$ and DNA bands were stained with SYBR Green.

\section{Statistics}

All results are given as mean \pm standard deviation except for Fig. 1e (mean $\pm 95 \%$ confidence intervals). Non-parametric statistical tests for two (Mann-Whitney) or multiple (Kruskal-Wallis) means were performed on GraphPad Prism. Errors bars for binding distributions of dCas12a, nucleosomes and dCas $12 a-S_{10}$ were generated by bootstrap analysis.

\section{Author Contributions and Notes}

A.H.G. and I.J.F. conceived the idea for this study and designed the experiments together with C.C.C. C.C.C. performed all the experiments and analyzed the data jointly with I.J.F. and A.H.G. I.J.F., A.H.G. and C.C.C. wrote the manuscript, which was read and approved by all authors.

This article contains supporting information online.

\section{Acknowledgments}

We thank the CONACyT-University of Texas (CONTEX) grant to carry out this research. A.H.G. also thanks the IA200119 DGAPAPAPIIT grant. This work was partially funded by the NIH (GM124141 to I.J.F.) and the Welch Foundation (F-1016 to I.J.F.). C.C.C. acknowledges the support of CONACyT for supporting his graduate studies at UT-Austin. We thank David Moreno Gutiérrez for providing some of the C-S ${ }_{10}-\mathrm{B}$ protein and all the members of A.H.G. and I.J.F. labs for valuable discussions. We also thank technicians and facilities of the Institute of Chemistry at UNAM and Tom Wandless at Stanford University for the kind donation of FKBP and FRB plasmids. The authors declare no competing interests.

\section{References}

1. Hernandez-Garcia, A. et al. Design and self-assembly of simple coat proteins for artificial viruses. Nat. Nanotechnol. 9, 698-702 (2014).

2. Werten, M. W. T., Wisselink, W. H., Jansen-van den Bosch, T. J., de Bruin, E. C. \& de Wolf, F. A. Secreted production of a customdesigned, highly hydrophilic gelatin in Pichia pastoris. Protein Eng. Des. Sel. 14, 447-454 (2001).

3. Krejchi, M. et al. Chemical sequence control of $\beta$-sheet assembly in macromolecular crystals of periodic polypeptides. Science 265, 1427-1432 (1994).

4. Smeenk, J. M. et al. Controlled Assembly of Macromolecular $\beta$ Sheet Fibrils. Angew. Chem. Int. Ed. 44, 1968-1971 (2005).

5. Zhao, B., Cohen Stuart, M. A. \& Hall, C. K. Dock ' $n$ roll: folding of a silk-inspired polypeptide into an amyloid-like beta solenoid. Soft Matter 12, 3721-3729 (2016).

6. Martin, M. E. \& Rice, K. G. Peptide-guided gene delivery. AAPS J. 9, E18-E29 (2007).

7. Hernandez-Garcia, A., Werten, M. W. T., Stuart, M. C., de Wolf, F. A. \& de Vries, R. Coating of Single DNA Molecules by Genetically Engineered Protein Diblock Copolymers. Small 8, 3491-3501 (2012).

8. Hernandez-Garcia, A., Cohen Stuart, M. A. \& de Vries, R. Templated co-assembly into nanorods of polyanions and artificial virus capsid proteins. Soft Matter 14, 132-139 (2017).

9. Punter, M. T. J. J. M., Hernandez-Garcia, A., Kraft, D. J., de Vries, R. \& van der Schoot, P. Self-Assembly Dynamics of Linear Virus-
Like Particles: Theory and Experiment. J. Phys. Chem. B 120 , 6286-6297 (2016).

10. Chai, S., Lurz, R. \& Alonso, J. C. The Small Subunit of the Terminase Enzyme of Bacillus subtilis Bacteriophage SPP1 forms a Specialized Nucleoprotein Complex with the Packaging Initiation Region. J. Mol. Biol. 252, 386-398 (1995).

11. Turner, D. R., Joyce, L. E. \& Butler, P. J. G. The tobacco mosaic virus assembly origin RNA. J. Mol. Biol. 203, 531-547 (1988).

12. D'Souza, V. et al. Identification of a high affinity nucleocapsid protein binding element within the moloney murine leukemia virus $\Psi$-RNA packaging signal: implications for genome recognition. J. Mol. Biol. 314, 217-232 (2001).

13. de Beer, T. et al. Insights into Specific DNA Recognition during the Assembly of a Viral Genome Packaging Machine. Mol. Cell 9, 981991 (2002).

14. Borodavka, A., Tuma, R. \& Stockley, P. G. Evidence that viral RNAs have evolved for efficient, two-stage packaging. Proc. Natl. Acad. Sci. 109, 15769-15774 (2012).

15. Kutluay, S. B. et al. Global Changes in the RNA Binding Specificity of HIV-1 Gag Regulate Virion Genesis. Cell 159, 1096-1109 (2014).

16. Stewart, $H$. et al. Identification of novel RNA secondary structures within the hepatitis C virus genome reveals a cooperative involvement in genome packaging. Sci. Rep. 6, 22952 (2016).

17. Patel, N. et al. Rewriting nature's assembly manual for a ssRNA virus. Proc. Natl. Acad. Sci. 114, 12255-12260 (2017).

18. Morton, V. L. et al. The Impact of Viral RNA on Assembly Pathway Selection. J. Mol. Biol. 401, 298-308 (2010).

19. Kraft, D. J., Kegel, W. K. \& van der Schoot, P. A Kinetic Zipper Model and the Assembly of Tobacco Mosaic Virus. Biophys. J. 102, 2845-2855 (2012).

20. Comas-Garcia, M. et al. Dissection of specific binding of HIV-1 Gag to the 'packaging signal' in viral RNA. eLife 6, e27055 (2017).

21. Comas-Garcia, M. Packaging of Genomic RNA in Positive-Sense Single-Stranded RNA Viruses: A Complex Story. Viruses 11, 253 (2019).

22. Strohkendl, I., Saifuddin, F. A., Rybarski, J. R., Finkelstein, I. J. \& Russell, R. Kinetic Basis for DNA Target Specificity of CRISPRCas12a. Mol. Cell 71, 816-824.e3 (2018).

23. Zetsche, B. et al. Multiplex gene editing by CRISPR-Cpf1 using a single crRNA array. Nat. Biotechnol. 35, 31-34 (2017).

24. Gallardo, I. F. et al. High-Throughput Universal DNA Curtain Arrays for Single-Molecule Fluorescence Imaging. Langmuir 31, 1031010317 (2015).

25. Soniat, M. M. et al. Next-Generation DNA Curtains for SingleMolecule Studies of Homologous Recombination. in Methods in Enzymology vol. 592 259-281 (Elsevier, 2017).

26. Miné, J. et al. Real-time measurements of the nucleation, growth and dissociation of single Rad51-DNA nucleoprotein filaments. Nucleic Acids Res. 35, 7171-7187 (2007).

27. Marchetti, M. et al. Real-Time Assembly of Viruslike Nucleocapsids Elucidated at the Single-Particle Level. Nano Lett. 19, 5746-5753 (2019).

28. Gao, L. et al. Engineered Cpf1 variants with altered PAM specificities increase genome targeting range. Nat. Biotechnol. 35, 789-792 (2017).

29. Leenay, R. T. \& Beisel, C. L. Deciphering, Communicating, and Engineering the CRISPR PAM. J. Mol. Biol. 429, 177-191 (2017).

30. Nishimasu, $\mathrm{H}$. et al. Engineered CRISPR-Cas9 nuclease with expanded targeting space. Science 361, 1259-1262 (2018).

31. Walton, R. T., Christie, K. A., Whittaker, M. N. \& Kleinstiver, B. P. Unconstrained genome targeting with near-PAMless engineered

CRISPR-Cas9 variants. Science (2020) doi:10.1126/science.aba8853 